\title{
Path Analysis on the Determinants of Health Cadres Ability in Early Detection and Management of Pregnancy Risk Factors in Sleman, Yogyakarta, Indonesia
}

\author{
Istri Yuliani'), Bhisma Murti'2), Endang Sutisna Sulaeman3), \\ Tedjo Danudjo Oepomo4) \\ 1)Doctoral Program in Community Development/Empowerment, \\ Universitas Sebelas Maret \\ 2)Masters Program in Public Health, Universitas Sebelas Maret \\ 3)Department of Public Health, Faculty of Medicine, Universitas Sebelas Maret \\ 4)Faculty of Medicine, Universitas Sebelas Maret
}

\begin{abstract}
Background: Every pregnant woman has the potential to experience risk, so it is necessary to get serious attention and special treatment by health workers, family, and community. One role of the community is as the health cadres. This study aimed to examine the determinants of health cadre ability in early detection and management of pregnancy risk factors.

Subjects and Method: The research used quantitative method and cross-sectional approach. There were 269 health cadres participating as research samples. The sampling technique used is multistage cluster random sampling. Data were collected using a questionnaire with a Likert scale. Data analysis is done using path analysis.

Results: Cadre's ability in early detection of pregnancy risk factors was affected by attitude $(b=$ $0.38 ; \mathrm{SE}=0.10 ; \mathrm{p}<0.001)$, experience $(\mathrm{b}=0.38 ; \mathrm{SE}=0.10 ; \mathrm{p}<0.001)$, motivation $(\mathrm{b}=0.63 ; \mathrm{SE}=0.14$; $\mathrm{p}<0.001)$, compensation ( $\mathrm{b}=0.68 ; \mathrm{SE}=0.19 ; \mathrm{p}<0.001)$, workload $(\mathrm{b}=0.64 ; \mathrm{SE}=0.23 ; \mathrm{p}=0.005)$, education and training $(\mathrm{b}=0.68 ; \mathrm{SE}=0.19 ; \mathrm{p}=0.001)$, supervision $(\mathrm{b}=0.99 ; \mathrm{SE}=0.17 ; \mathrm{p}<0.001)$, perceived seriousness $(b=0.73 ; \mathrm{SE}=0.16 ; \mathrm{p}<0.001)$, and perceived benefit $(\mathrm{b}=0.84 ; \mathrm{SE}=0.18$; $\mathrm{p}<0.001)$. Cadre's ability in the management of pregnancy risk factors was affected by attitude $(b=$ $0.54 ; \mathrm{SE}=0.12 ; \mathrm{p}<0.001)$, experience $(\mathrm{b}=0.18 ; \mathrm{SE}=0.10 ; \mathrm{p}=0.079)$, motivation $(\mathrm{b}=0.36 ; \mathrm{SE}=0.15$; $\mathrm{p}=0.014)$, compensation $(\mathrm{b}=0.64 ; \mathrm{SE}=0.20 ; \mathrm{p}=0.001)$, supervision $(\mathrm{b}=0.36 ;(b=0.49 ; \mathrm{SE}=0.18$; $\mathrm{p}=0.008)$, and early detection of pregnancy risk factors $(\mathrm{b}=0.29 ; \mathrm{SE}=0.05 ; \mathrm{p}<0.001)$.

Conclusion: Cadre's ability in early detection of pregnancy risk factors is affected by attitude, experience, motivation, compensation, workload, education and training, supervision, perceived seriousness, and perceived benefit. Cadre's ability in the management of pregnancy risk factors is affected by attitude, experience, motivation, compensation, supervision, and early detection of pregnancy risk factors
\end{abstract}

Keywords: health cadres, early detection, management, pregnancy risk factors, path analysis

\section{Correspondence:}

Istri Yuliani. Doctoral Program in Community Development/Empowerment, Universitas Sebelas Maret. Jl. Ir. Sutami 36A, Surakarta 57126, Central Java, Indonesia. Email: istriyuliani1@gmail.com. Mobile: 08122796697

\section{BACKGROUND}

Maternal health is one of the main problems in the world. Pregnant women, childbirth and childbirth are groups that are prone to health problems, so they need to get serious attention and special treatment to prevent the occurrence of maternal deaths (Ministry of Health of the Republic of Indonesia, 2011). The maternal mortality rate (MMR) in Indonesia was 305/100,000 live births births (Statistics Indonesia, 2016), the highest in Southeast Asia. Direct maternal mortality is caused by bleeding (32\%), eclampsia (26\%), infection (others 
Journal of Health Policy and Management (2019), 4(1): 47-58

https://doi.org/10.26911/thejhpm.2019.04.01.06

29\%), infection (5\%), circulatory system disorders (5\%) (Ministry of Health of the Republic of Indonesia, 2016). Meanwhile, other problems also play a significant role in causing maternal deaths. This problem concerns social and cultural dynamics. Women have difficulty accessing existing resources due to poverty, discrimination on the basis of race, gender inequality, and criminalization of abortion. Moreover, women prone to pregnancy problems are caused by the practice of early marriage (and teenage pregnancy), high fertility rates which can increase the potential for obstructed births, patriarchal customs that make women's health, nutrition and education not important, so that this condition trigger pregnancy with risk factors. Basically, every pregnant woman can experience the risk of complications in labor, both in low-risk pregnant women, especially in high-risk pregnant women (Rochjati, 2011).

Efforts to accelerate the reduction of MMR can be done by ensuring that every mother is able to access quality maternal health services, such as maternal health services, delivery assistance by trained health workers in health care facilities, postpartum care for mothers, special care and referral in the event of complications. But the reality of maternal death is not that simple. On one hand, indeed access to health before, for a moment, and after birth will reduce the incidence of maternal deaths. But there are other more complex factors that need to be considered. Efforts to reduce MMR are not only the responsibility of the health sector, but also need to involve cross-sectoral roles and the role of the community. The role of the community here, one of which is involvement in becoming a health cadre (Departemen Kesehatan RI, 2009). Health cadres are community members chosen from and by the community, willing and able to work together in various voluntary community activities (Lehmann and Sanders, 2007). Health cadres have an important role and contribute to the reduction of MMR through early detection and management of risk factors for pregnancy.

To achieve the success of efforts to reduce MMR through early detection and management of pregnancy risk factors, it is necessary to study the ability of health cadres and the factors that influence them. The ability of health care cadres in managing pregnancy risk factors is an indicator of intellectual behavior (Azwar, 2006).

Health cadres who are voluntarily motivated to serve the health sector, should have sufficient educational background, so as to enable them to analyze health problems that occur in the community. Health cadres are required to have knowledge and skills in accordance with the tasks carried out, so that they can be effective in carrying out their roles, both in empowering the community and in the role of efforts to reduce maternal mortality (Iswarawanti, 2010). Health health cadres must also receive continuous guidance both with supervision and education and training. Continuous supervision, guidance, education and training can improve health cadre performance (Kok et al., 2015)..

The role of health cadres in efforts to reduce AKI through early detection and management of pregnancy risk factors is very important, so the purpose of this study is to determine the determinants of the ability of health cadres in early detection and management of risk factors for pregnancy.

\section{SUBJECTS AND METHOD}

This was is a quantitative study with a cross-sectional design. The data were collected from February 7 to May 5, 2016. The population of the study was active 
health cadres at 25 health centers in Sleman Regency with a total of 892 people. A sample of 269 active health cadres was collected by multistage cluster random sampling.

The dependent variables were the ability of health cadres in early detection and management of risk factors for pregnancy. The independent variables were age, attitude, experience, motivation, compensation, supervision, workload, education and training, supervision, perceptions of seriousness and perceptions of benefits.

Table 1. Sample Characteristics

\begin{tabular}{clcc}
\hline \multicolumn{1}{c}{ Characteristics } & \multicolumn{1}{c}{ Criteria } & n & Percentage (\%) \\
\hline Education & Primary School & 66 & 24.54 \\
& High School & 166 & 61.71 \\
& College & 37 & 13.75 \\
Occupation & Housewife & 199 & 73.98 \\
& Civil Servant & 1 & 0.37 \\
& Private employee & 69 & 25.65 \\
\hline
\end{tabular}

\section{Univariate Analysis}

Mostly the cadres were at age $36-50$ years old $(58.74 \%)$. For the attitude, most of them $(68.4 \%)$ is in the category of quite good. For the experience, more people have $>5$ years experience than those $<5$ years. For the motivation, mostly (82.9\%) are in the fairly good category. For the compensation, most of them (77.0\%) are in the bad category. Related to the workload, most of them (60.6\%) are in the fairly good category.

Most of the sample (44.6\%) had low education and training, 50.2\% received low supervision. As many as 56.9\% samples had strong perceived seriousness. As many as 59.5\% samples had strong perceived benefit. As many as 59.5\% cadres had good ability in the early detection on the risk factors of pregnancy. As many as $47.6 \%$ cadres had poor ability in managing the risk factors among pregnant women.
The data were analyzed by path analysis, which consisted of 5 steps: (1) model specification, (2) model identification, (3) model fit, (4) parameter estimation, and (5) re-specification model.

\section{RESULTS}

\section{Sample Characteristics}

Table 1 showed sample characteristics. Table 1 showed that the majority the sample had secondary education and worked as housewife.

\section{Bivariate Analysis}

Table 3 showed that the higher the score of attitude, experience, motivation, compensation, workload, education and training, supervision, perceived benefit, and perceived seriousness, the higher the ability of health cadres in early detection of risk factors for pregnancy.

The higher the score of attitude, experience, motivation, compensation, supervision, and early detection, the higher the ability of health cadres in managing pregnancy risk factors.

The older the age, the higher the experience of health cadres. The older the age of the health cadre, the more frequent the supervision received by health cadres. The higher the motivation score and experience score, the higher the compensation obtained. 
Journal of Health Policy and Management (2019), 4(1): 47-58

https://doi.org/10.26911/thejhpm.2019.04.01.06

Table 2. Frequency distribution of respondents according to research variables

\begin{tabular}{|c|c|c|c|}
\hline Variable & Criteria & Total & Percentage (\%) \\
\hline \multirow[t]{4}{*}{ Age } & $<21$ & 1 & 0.37 \\
\hline & 21-35 & 58 & 21.56 \\
\hline & $36-50$ & 158 & 58.74 \\
\hline & $>50$ & 52 & 19.33 \\
\hline \multirow[t]{4}{*}{ Behaviour } & Good & 78 & 29.00 \\
\hline & Fair & 184 & 68.40 \\
\hline & Not so fair & 7 & 2.60 \\
\hline & Poor & $\mathrm{O}$ & 0.00 \\
\hline \multirow[t]{4}{*}{ Experience } & $<5$ years & 93 & 34.60 \\
\hline & $5^{-}<10$ years & 59 & 21.90 \\
\hline & $10-<15$ years & 47 & 17.50 \\
\hline & $\geq 15$ years & 70 & 26.00 \\
\hline \multirow{4}{*}{ Motivation } & Good & 43 & 16.00 \\
\hline & Fair & 223 & 82.90 \\
\hline & Not so fair & 3 & 1.10 \\
\hline & Poor & $\mathrm{O}$ & 0.00 \\
\hline \multirow[t]{4}{*}{ Compensation } & Good & 0 & 0.00 \\
\hline & Fair & 5 & 1.90 \\
\hline & Not so fair & 57 & 21.19 \\
\hline & Poor & 207 & 76.95 \\
\hline \multirow{4}{*}{ Working load } & Good & $\mathrm{o}$ & 0.00 \\
\hline & Fair & 163 & 60.60 \\
\hline & Not so fair & 106 & 39.40 \\
\hline & Poor & 0 & 0,00 \\
\hline \multirow[t]{4}{*}{ Education and training } & Good & 9 & $3 \cdot 35$ \\
\hline & Fair & 53 & 19.70 \\
\hline & Not so fair & 120 & 44.61 \\
\hline & Poor & 87 & 32.34 \\
\hline \multirow[t]{4}{*}{ Supervision } & Good & $\mathrm{O}$ & 0.00 \\
\hline & Fair & 27 & 10.00 \\
\hline & Not so fair & 107 & 39.80 \\
\hline & Poor & 135 & 50.20 \\
\hline \multirow[t]{4}{*}{ Seriousness perception } & Good & 32 & 11.90 \\
\hline & Fair & 153 & 56.90 \\
\hline & Not so fair & 79 & 29.30 \\
\hline & Poor & 5 & 1.90 \\
\hline \multirow[t]{4}{*}{ Benefits perception } & Good & 90 & 33.40 \\
\hline & Fair & 160 & 59.50 \\
\hline & Not so fair & 19 & 7.10 \\
\hline & Poor & $\mathrm{O}$ & 0.00 \\
\hline \multirow{4}{*}{$\begin{array}{l}\text { The ability of health cadres in } \\
\text { early detection of risk factors for } \\
\text { pregnancy }\end{array}$} & Good & 25 & 9.29 \\
\hline & Fair & 160 & 59.48 \\
\hline & Not so fair & 72 & 26.77 \\
\hline & Poor & 12 & 4.46 \\
\hline \multirow{4}{*}{$\begin{array}{l}\text { Health cadres' ability to manage } \\
\text { pregnancy risk factors }\end{array}$} & Good & 8 & 3.00 \\
\hline & Fair & 70 & 26.00 \\
\hline & Not so fair & 128 & 47.60 \\
\hline & Poor & 63 & 23.40 \\
\hline
\end{tabular}


Yuliani et al./ Path Analysis on the Deterninants of Health Cadres Ability

Table 3. Determinants of the ability of health cadres in early detection and management of risk factors for pregnancy

\begin{tabular}{llcc}
\hline Dependent Variable & Independent Variable & $\mathbf{r}$ & p \\
\hline The ability of cadres in early detection & Attitude & 0.23 & $<0.001$ \\
of risk factors for pregnancy & Experience & 0.17 & $<0.001$ \\
& Motivation & 0.20 & $<0.001$ \\
& Compensation & 0.16 & $<0.001$ \\
& Workload & 0.12 & 0.005 \\
& Education and training & 0.24 & $<0.001$ \\
& Supervision & 0.25 & $<0.001$ \\
& Perception of seriousness & 0.20 & $<0.001$ \\
& Perception of benefits & 0.21 & $<0.001$ \\
Cadre's ability to manage pregnancy & Attitude & 0.23 & $<.001$ \\
risk factors & Experience & 0.09 & 0.079 \\
& Motivation & 0.12 & 0.014 \\
& Compensation & 0.16 & 0.001 \\
& Supervision & 0.13 & 0.008 \\
& Early Detection & 0.31 & $<0,001$ \\
Experience & Age & 0.56 & $<0.001$ \\
Supervision & Age & 0.13 & $<0.005$ \\
Compensation & Motivation & 0.11 & 0.047 \\
& Experience & 0.24 & $<0.001$ \\
\hline
\end{tabular}

\section{Path Analysis}

This study had 12 observed variables. Degree of freedom was 26 (over identified). The value of the goodness of fit including $\mathrm{CMIN}=1.49 ; \mathrm{p}=0.52 ; \mathrm{GFI}=0.98, \mathrm{AGFI}=$ 0.93; $\mathrm{NFI}=0.93$; $\mathrm{CFI}=0.97$; and RMSEA $=$ 0.04. The results of this measurement can be interpreted that the empirical model has fulfilled the criteria specified and it was in accordance with empirical data. Figure 1 showed the structural model with unstandardized solution. The model in the study did not need to be respecified because the output of the model designed was in accordance with the provisions of the model, which was in accordance with the sample data shown by the saturation model and the regression coefficient which was more than zero.

Table 4 showed that cadre's ability in early detection of pregnancy risk factors was affected by attitude $(b=0.38 ; \mathrm{SE}=0.10$; $\mathrm{p}<0.001)$, experience $(\mathrm{b}=0.38 ; \mathrm{SE}=0.10$; $\mathrm{p}<0.001)$, motivation $(\mathrm{b}=0.63 ; \mathrm{SE}=0.14$; $\mathrm{p}<0.001)$, compensation $(\mathrm{b}=0.68 ; \mathrm{SE}=0.19$; $\mathrm{p}<0.001$ ), workload ( $\mathrm{b}=0.64 ; \mathrm{SE}=0.23 ; \mathrm{p}=$ $0.005)$, education and training $(b=0.68$; $\mathrm{SE}=0.19 ; \mathrm{p}=0.001)$, supervision $(\mathrm{b}=0.99$; $\mathrm{SE}=0.17 ; \mathrm{p}<0.001)$, perceived seriousness $(b=0.73 ; \mathrm{SE}=0.16 ; \mathrm{p}<0.001)$, and perceived benefit $(b=0.84 ; S E=0.18 ; p<0.001)$.

Cadre's ability in the management of pregnancy risk factors was affected by attitude $(\mathrm{b}=0.54 ; \mathrm{SE}=0.12 ; \mathrm{p}<0.001)$, experience $(b=0.18 ; S E=0.10 ; p=0.079)$, motivation $(b=0.36 ; S E=0.15 ; p=0.014)$, compensation $(b=0.64 ; S E=0.20 ; p=0.001)$, supervision $(b=0.36 ;(b=0.49 ; \mathrm{SE}=0.18$; $\mathrm{p}=0.008$ ), and early detection of pregnancy risk factors $(b=0.29 ; \mathrm{SE}=0.05 ; \mathrm{p}$ $<0.001)$. 
Journal of Health Policy and Management (2019), 4(1): 47-58

https://doi.org/10.26911/thejhpm.2019.04.01.06

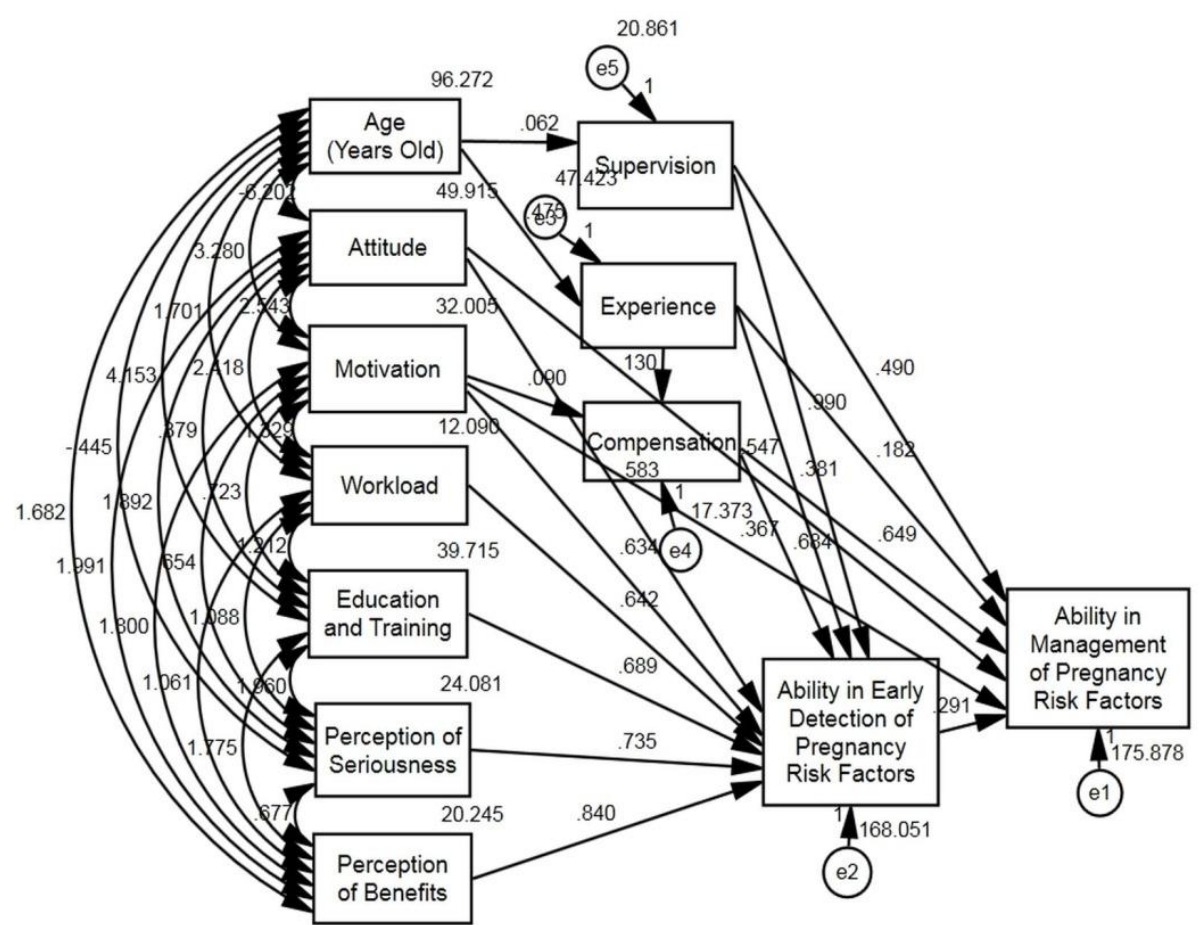

Figure 1. Structural model with unstandardized solution

Table 4. The Result of Path Analysis

\begin{tabular}{|c|c|c|c|c|c|c|}
\hline $\begin{array}{l}\text { Dependent } \\
\text { Variables }\end{array}$ & & $\begin{array}{l}\text { Independent } \\
\text { Variables }\end{array}$ & b & SE & $\mathbf{p}$ & $\boldsymbol{\beta}$ \\
\hline \multicolumn{7}{|l|}{ Direct Effect } \\
\hline Early Detection & $\leftarrow$ & Attitude & 0.58 & 0.11 & $<0.001$ & 0.23 \\
\hline Early Detection & $\leftarrow$ & Experience & 0.38 & 0.09 & $<0.001$ & 0.17 \\
\hline Early Detection & $\leftarrow$ & Motivation & 0.63 & 0.14 & $<0.001$ & 0.20 \\
\hline Early Detection & $\leftarrow$ & Compensation & 0.68 & 0.19 & $<0.001$ & 0.16 \\
\hline Early Detection & $\leftarrow$ & Workload & 0.64 & 0.23 & 0.005 & 0.12 \\
\hline Early Detection & $\leftarrow$ & $\begin{array}{l}\text { Education and } \\
\text { Training }\end{array}$ & 0.68 & 0.12 & $<0.001$ & 0.24 \\
\hline Early Detection & $\leftarrow$ & Supervision & 0.99 & 0.17 & $<0.001$ & 0.25 \\
\hline Early Detection & $\leftarrow$ & $\begin{array}{l}\text { Perceived } \\
\text { Seriousness }\end{array}$ & 0.73 & 0.16 & $<0.001$ & 0.20 \\
\hline Early Detection & $\leftarrow$ & Perceived Benefit & 0.84 & 0.18 & $<0.001$ & 0.21 \\
\hline Management & $\leftarrow$ & Attitude & 0.54 & 0.12 & $<0.001$ & 0.23 \\
\hline Management & $\leftarrow$ & Experience & 0.18 & 0.10 & 0.079 & 0.09 \\
\hline Management & $\leftarrow$ & Motivation & 0.36 & 0.15 & 0.014 & 0.12 \\
\hline Management & $\leftarrow$ & Compensation & 0.64 & 0.19 & 0.001 & 0.17 \\
\hline Management & $\leftarrow$ & Supervision & 0.49 & 0.18 & 0.008 & 0.13 \\
\hline Management & $\leftarrow$ & Early Detection & 0.29 & 0.05 & $<0.001$ & 0.31 \\
\hline \multicolumn{7}{|l|}{ Indirect Effect } \\
\hline Experience & $\leftarrow$ & Age & 0.47 & 0.43 & $<0.001$ & 0.56 \\
\hline Supervision & $\leftarrow$ & Age & 0.06 & 0.28 & 0.030 & 0.13 \\
\hline Compensation & $\leftarrow$ & Motivation & 0.09 & 0.04 & 0.047 & 0.11 \\
\hline $\begin{array}{l}\text { Compensation } \\
\text { Fit Model }\end{array}$ & $\leftarrow$ & Experience & 0.13 & 0.03 & $<0.001$ & 0.24 \\
\hline \multicolumn{4}{|l|}{ Fit Model } & & & \\
\hline GFI & $=0.98$ & $\geq 0.90$ & & & & \\
\hline AGFI & $=0,93$ & $\geq 0.90$ & & & & \\
\hline NFI & $=0.93$ & $\geq 0.90$ & & & & \\
\hline CFI & $=0.97$ & $\geq 0.95$ & & & & \\
\hline RMSEA & $=0.04$ & $\leq 0.08$ & & & & \\
\hline
\end{tabular}




\section{DISCUSSIONS \\ 1. Determinants of health cadres ability in early detection of risk factors for pregnancy}

Attitude were positively and significantly associated with the ability of health cadres in early detection of risk factors for pregnancy. A strong attitude was a predictor of good behavior. Attitudes can have a very strong influence on a person's behavior or vice versa, attitudes would not affect someone if it was not related to their lives (LaPiere, 1934). Attitude toward a behavior were determined by beliefs in a behavior (behavior beliefs) and the costs or benefits of the behavior (Ajzen, 2005). Based on this opinion, health cadres who have a positive attitude towards risk factors for pregnancy would prevent the occurrence of risk factors for pregnancy, because pregnancy risk factors can threaten maternal and infant health.

Experience has a positive and significant influence on the ability of health cadres in early detection of risk factors for pregnancy. Experience was a knowledge or skill that has been known and mastered by someone who was the result of an act or work that has been done for some time (Kambarami et al., 2016). These results were in accordance with previous studies which stated that health cadres with a longer duration of work were able to recognize the health problems of pregnant women more (Hariwibowo et al., 2012). The experience of health cadres was measured by looking at the length of work to become a health cadre. Health cadres with a longer working period were believed to have had various experiences in solving various health problems.

Motivation has a positive and significant influence on the ability of health cadres in early detection of risk factors for pregnancy. Motivated health workers can do their job effectively (Aduo-Adjei et al., 2016). The main motivations of health cadre in work were social honor, moral and religious obligations (Glenton et al., 2010). Health cadres can be maintained and motivated by factors other than wages. Obtaining and sharing experiences with community members, building relationships between cadres and the community, has a higher value than just being appointed as an employee or getting transport money (Singh et al., 2016).

Compensation has a positive and significant effect on the ability of health cadres in early detection of risk factors for pregnancy. Compensation did not have to be in the form of money or salary, but can be in the form of awards. Appreciation was a factor that facilitate the growth of community participation (Ife and Tesoriero, 2008). Government funding support was also one of the factors associated with cadres' ability to solve local health problems (Sulaeman et al., 2012). Awards in financial or other forms were also important to maintain and manage the involvement and motivation of health cadres (Takasugi and Lee, 2012).

Workload influenced the ability of health cadres in early detection of pregnancy risk factors, the better the workload, the higher the ability of health care cadres in early detection of risk factors for pregnancy. A good workload was a workload that was not too low or too high. The results showed that $60.6 \%$ of health cadres had a fairly good workload. A worker has good performance qualitatively and quantitatively when the workload was at a moderate level (moderate) (Bruggen, 2015).

Education and training have a positive and significant effect on the ability of health cadres in early detection of risk factors for pregnancy. Health cadres lack skills due to lack of program orientation, education and support for their role (Gau et al., 
Journal of Health Policy and Management (2019), 4(1): 47-58

https://doi.org/10.26911/thejhpm.2019.04.01.06

2013). Training on health cadres has a positive effect in increasing knowledge and having a positive effect on their self-confidence (Yang et al., 2018). Training for health cadres can also increase the level of public recognition and satisfaction with their performance (Kawasaki et al., 2015).

Supervision has a positive and significant effect on the ability of health cadres in early detection of risk factors for pregnancy. Previous research showed that supportive supervision can increase the productivity of health cadres (Frimpong et al., 2011). Continuous supervision can also help to maintain cadres' interest and motivation in carrying out their duties (Curtale et al., 1995).

The perception of health cadres about the seriousness of pregnancy risk factors has a positive and significant influence on the ability of health cadres in early detection of risk factors for pregnancy. Health cadres with high perceived seriousness have a greater proportion to detect early risk factors for pregnancy. In contrast, health cadres with a low perceived seriousness have a greater proportion to not conduct early detection of risk factors for pregnancy (Fibriana, 2013).

The perception of health cadres about the benefits of early detection of pregnancy risk factors has a positive and significant influence on the ability of health cadres in early detection of risk factors for pregnancy. Perceived benefits were predictors of behavior (Zhao et al., 2012). In this study, the perception of health cadres about the benefits of early detection of pregnancy risk factors was mostly (59.5\%) in the fairly good category. This showed that health cadres have confidence in the benefits/ advantages obtained if they conducted early detection and risk factors for pregnancy.

\section{Determinants of health cadres ability in pregnancy risk factor management}

Attitude had a positive and significant effect on the ability of health cadres in managing risk factors for pregnancy. A behavior would produce positive consequences so individuals would tend to be favorable towards the behavior, on the contrary, individuals who have a negative evaluation attitude towards individual behavior would tend to be unfavorable towards the behavior. Health cadres who felt that there were serious health problems, have the desire to get training in how to detect early health problems, so that they can carry out early detection and manage health problems at the community level (Neupane et al., 2017).

Experience has a positive and significant effect on the ability of health cadres in managing risk factors for pregnancy. Health cadres with more experience have better creativity and innovation so that they can manage pregnancy risk factors by implementing various strategies (Coatsworth et al., 2017).

Motivation has a positive and significant effect on the ability of health cadres in managing risk factors for pregnancy. Motivation can improve work performance of health cadres. Highly motivated individuals can overcome various obstacles such as poor work environments, concerns about personal security and inadequate equipment (Luoma, 2006). One of the main motivating factors for health personnels included appreciation from managers, colleagues and communities, stable work and salary and training (Dieleman et al., 2003). However, despite not receiving a salary, health cadres have an intrinsic desire to volunteer, and their motivation often comes from the support they received from their families, when other sources of 
motivation were insufficient (Greenspan et al., 2013).

Compensation has a positive and significant effect on the ability of health cadres in managing pregnancy risk factors. Compensation was not the only factor that influenced the ability of health cadres in managing pregnancy risk factors, but compensation for health cadres needed to be considered because compensation was also expected by health cadres. Compensation did not have to be in the form of money, but can be given in other forms, for example by holding a family gathering for health cadres, recreation, giving uniforms and others. Awards, whether financial or non-financial, were important for health cadres (Takasugi and Lee, 2012).

Supervision has a positive and significant influence on the ability of health cadres in managing risk factors for pregnancy. Supervision activities would have a good impact and guarantee a high standard of service quality if it was done well. Supervision can increase the motivation of health cadres in carrying out their duties (Curtale et al., 1995). Supervision was also a factor that affected the retention and motivation of health cadres (Strachan et al., 2012).

The ability of health cadres in early detection of pregnancy risk factors has a positive and significant effect on the ability of health cadres in managing risk factors for pregnancy. Early detection by health cadres about the existence of risk factors and complications of pregnancy, as well as adequate management as early as possible, was the key to success in reducing maternal and neonatal mortality (Departemen Kesehatan RI, 2009).

Age has a positive and significant influence on experience. Age also has a positive and significant effect on supervision. This showed that older cadres have more experience and have received more supervision. According to Hariastuti, experience can increase success in community empowerment (Hariastuti, 2014). Continous supervision conducted by professional staff can increase the effectiveness of health cadres in providing services to clients (Snowdon et al., 2017).

Motivation and experience have a positive and significant effect on compensation. Motivated cadres usually have better performance (Aduo-Adjei et al., 2016), so the award received was better. Awards, whether in the form of financial or other awards, were important for maintaining and managing the involvement and motivation of health cadres (Takasugi and Lee, 2012). Work experience was one of the predictors of compensation. The longer the work experience, the greater the compensation received (Knighton et al., 2018).

Determinants of the ability of health cadres in early detection of pregnancy risk factors include: attitude, experience, motivation, compensation, workload, education and training, supervision, perceived seriousness and perceived benefits. Determining the ability of health cadres in managing pregnancy risk factors included: attitude, experience, motivation, compensation, supervision and ability of health cadre in early detection of pregnancy risk factors, while experience and supervision were influenced by age, compensation was influenced by motivation and experience.

\begin{tabular}{l}
\hline REFERENCE \\
\hline Aduo-Adjei K, Emmanuel O, Forster, OM \\
(2016). The impact of motivation on \\
the work performance of health work- \\
ers (Korle Bu Teaching Hospital): \\
evidence from Ghana. Hospital Prac- \\
tices and Research, 1(2): 47-52.
\end{tabular}

Ajzen I (2005). Attitudes, personality, and behavior. UK: McGraw-Hill Education. 
Journal of Health Policy and Management (2019), 4(1): 47-58

https://doi.org/10.26911/thejhpm.2019.04.01.06

Azwar S (2006). Pengantar psikologi inteligensi. Yogyakarta: Pustaka Pelajar.

Bruggen A (2015). An empirical investigation of the relationship between workload and performance. Management Decision, 53(10): 2377-2389.

Coatsworth K, Hurley J, Miller-Rosser K (2017). A phenomenological study of student nurses volunteering in Nepal: Have their experiences altered their understanding of nursing? Collegian, 24(4): 339-344.

Curtale F, Siwakoti, B, Lagrosa C, LaRaja M, Guerra R (1995). Improving skills and utilization of community health volunteers in Nepal. Social Science and Medicine, 40(8): 1117-1125.

Departemen Kesehatan RI (2009). Pedoman Pemantauan Wilayah Setempat Kesehatan Ibu dan Anak (PWS-KIA). Jakarta: Departemen Kesehatan RI.

Dieleman M, Cuong PV, Anh LV, Martineau $\mathrm{T}$ (2003). Identifying factors for job motivation of rural health workers in North Viet Nam. Human Resources for Health, 1(1): 10.

Fibriana AI (2013). Keikutsertaan pelanggan wanita pekerja seks dalam Voluntary Conseling And Testing (VCT). Jurnal Kesehatan Masyarakat, 8(2).

Frimpong JA, Helleringer S, AwoonorWilliams JK, Yeji F, Phillips, JF (2011). Does supervision improve health worker productivity? Evidence from the Upper East Region of Ghana. Tropical Medicine and International Health, 16(10): 1225-1233.

Gau YM, Buettner P, Usher K, Stewart L (2013). Burden experienced by community health volunteers in Taiwan: a survey. BMC Public Health, 13(1): 491.

Glenton C, Scheel IB, Pradhan S, Lewin S, Hodgins S, Shrestha V (2010). The female community health volunteer programme in Nepal: decision makers' perceptions of volunteerism, payment and other incentives. Social Science and Medicine, 70(12): 19201927.

Greenspan JA, McMahon SA, Chebet JJ, Mpunga M, Urassa DP, Winch PJ (2013). Sources of community health worker motivation: a qualitative study in Morogoro Region, Tanzania. Human Resources for Health, 11(1): 52.

Hariastuti I (2014). Factors effecting cadre's efficacy in improving acceptability in contraceptive service in Surabaya municipality. Scientific Research Journal, 2(6): 8.

Hariwibowo R, Marcelena R, Kurniawan R, Listiarini S, Putri SR, Firdaus S, Prabu D, Moegni F (2012). Level of education as the determinant factor of obstetric outpatients' knowledge about intra uterine device in Kramat Jati Public Health Center. Obstet Gynecol, 36(1): 5 .

Ife $\mathrm{J}$, Tesoriero $\mathrm{F}$ (2008). Alternatif pengembangan masyarakat di era globalisasi. Yogyakarta: Pustaka Pelajar.

Iswarawanti DN (2010). Posyandu cadres: their roles and challenges in empowerment for improving children nutritional status in Indonesia. Jurnal Manajemen Pelayanan Kesehatan, 13(04): 169-173.

Kambarami RA, Mbuya MNN, Pelletier D, Fundira D, Tavengwa NV Stoltzfus RJ (2016). Factors associated with community health worker performance differ by task in a multi-tasked setting in rural Zimbabwe. Global Health: Science and Practice, 4(2): 238-250.

Kawasaki R, Sadamori T, de Almeida TF, Akiyoshi M, Nishihara M, Yoshimura T, Ohnishi M (2015). Reactions of community members regarding com- 
munity health workers' activities as a measure of the impact of a training program in Amazonas, Brazil. Journal of Rural Medicine, 10(1): 7-19.

Knighton SC, Gilmartin HM, Reese, SM (2018). Factors affecting annual compensation and professional development support for infection preventionists: Implications for recruitment and retention. American Journal of Infection Control, 46(8): 865-869.

Kok MC, Dieleman M, Taegtmeyer M, Broerse JE, Kane SS, Ormel H, Tijm MM (2015). Which intervention design factors influence performance of community health workers in low- and middle-income countries? A systematic review. Health Policy and Planning, 30(9): 1207-1227.

LaPiere RT (1934). Attitudes vs. actions. Social Forces, 13(2): 230-237.

Lehmann U, Sanders D (2007). Community health workers: what do we know about them? The state of the evidence on programmes, activities, costs and impact on health outcomes of using community health workers. Geneva: World Health Organization.

Luoma M (2006). Increasing the motivation of health care workers. Capacity Project. Technical brief 7. Chapel Hill, N.C: IntraHealth International Inc.

Ministry of Health of the Republic of Indonesia (2011). Pedoman Pelaksanaan Kelas Ibu Hamil. Jakarta: Ministry of Health of the Republic of Indonesia.

Ministry of Health of the Republic of Indonesia (2016). Data rutin direktorat kesehatan keluarga 2014-2016. Jakarta: Ministry of Health of the Republic of Indonesia.

Murti B (2013). Desain dan ukuran sampel untuk penelitian kuantitatif dan kualitatif di bidang kesehatan. Yogyakarta: Gadjah Mada University Press.
Neupane D, McLachlan CS, Mishra SR, Kallestrup P (2017). Understanding and motivations of female community health volunteers about blood pressure control. Global Heart, 12(3): 227-232.

Rochjati P (2011). Skrining antenatal pada ibu hamil: pengenalan faktor risiko deteksi dini ibu hamil risiko tinggi (2nd ed.). Surabaya: Airlangga University Press.

Singh D, Cumming R, Mohajer N, Negin J (2016). Motivation of community health volunteers in rural Uganda: the interconnectedness of knowledge, relationship and action. Public Health, 136: 166-171.

Snowdon DA, Leggat SG, Taylor NF (2017). Does clinical supervision of healthcare professionals improve effectiveness of care and patient experience? A systematic review. BMC Health Services Research, 17(1): 786.

Statistics Indonesia (2016). Profile of the people of Indonesia SUPAS result 2015. Statistics Indonesia.

Strachan DL, Källander K, ten Asbroek AH, Kirkwood B, Meek SR, Benton L, Conteh L, Tibenderana J, Hill Z (2012). Interventions to improve motivation and retention of community health workers delivering integrated community case management (iC$\mathrm{CM}$ ): stakeholder perceptions and priorities. The American Journal of Tropical Medicine and Hygiene, 87(5 Suppl): 111-119.

Sulaeman ES, Karsidi R, Murti B, Kartono DT, Waryana W, Hartanto R. (2012). Model pemberdayaan masyarakat bidang kesehatan, studi program desa siaga. Kesmas: National Public Health Journal, 7(4): 186-192.

Takasugi T, Lee ACK (2012). Why do community health workers volunteer? 
Journal of Health Policy and Management (2019), 4(1): 47-58

https://doi.org/10.26911/thejhpm.2019.04.01.06

A qualitative study in Kenya. Public Health, 126(10): 839-845.

Yang BX, Stone TE, Davis SA (2018). The effect of a community mental health training program for multidisciplinary staff. Archives of Psychiatric Nursing, 32(3): 413-417.
Zhao J, Song F, Ren S, Wang Y, Wang L, Liu W, Wan Y, Xu H, et al. (2012). Predictors of condom use behaviors based on the Health Belief Model (HBM) among female sex workers: a cross-sectional study in Hubei Province, China. PLoS One, 7(11): e49542. 